\title{
Rapeseed population arrangement defined by adaptability and stability parameters
}

\author{
Cleusa A. M. B. Krüger ${ }^{1}$, Sandro L. P. Medeiros ${ }^{2}$, José A. G. da Silva ${ }^{1}$, \\ Genei A. Dalmago ${ }^{3}$, Ana P. F. Valentini ${ }^{4} \&$ Juliano F. Wagner ${ }^{4}$ \\ ${ }^{1}$ Universidade Regional do Noroeste do Estado do Rio Grande do Sul/Departamento de Estudos Agrários. Ijuí, RS. E-mail: cleusa.bianchi@unijui.edu.br \\ (Corresponding author); jagsfaem@yahoo.com.br \\ ${ }^{2}$ Universidade Federal de Santa Maria/Centro de Ciências Rurais. Santa Maria, RS. E-mail: slpmedeiros@yahoo.com.br \\ ${ }^{3}$ Embrapa Trigo. Passo Fundo, RS. E-mail: genei.dalmago@embrapa.br \\ ${ }^{4}$ Bayer CropScience/Unidade de Pesquisa Cruz Alta. Cruz Alta, RS. E-mail: ana.fontanavalentini@yahoo.com.br; juliano.wagner@yahoo.com.br
}

\section{Key words:}

Brassica napus L. inter-row spacing plant density grain yield

\begin{abstract}
A B S T R A C T
The objective of this study was to identify the plant arrangement that allows greater grain yield with adaptability and stability of rapeseed hybrids. The experiments were conducted in randomized block design with four replicates and the 12 treatments consisted of combination of inter-row spacings $(0.20,0.40$, and $0.60 \mathrm{~m})$ and plant densities $(20,40,60$ and 80 plants $\mathrm{m}^{-2}$ ). The hybrids Hyola 432 (early cycle) and Hyola 61 (medium cycle) were cultivated in three growing seasons $(2008,2009$ and 2010). Grain yield was evaluated based on the parameters adaptability and stability according to the models of Wricke and Eberhart \& Russell. The plant arrangement for obtaining higher grain yield depends on the cultivated genotype. Higher grain yield was obtained in the arrangements of $0.20 \mathrm{~m}$ x 60 and $0.40 \mathrm{~m}$

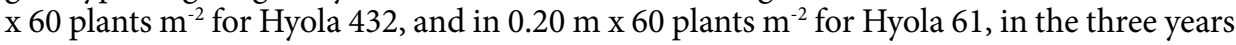
of evaluation. In the inter-row spacing of $0.40 \mathrm{~m}$ and densities of 40 and 60 plants $\mathrm{m}^{-2}$, Hyola 432 shows high yield, adaptability to wide environments and stability. For Hyola 61, high productivity with overall adaptability was obtained in the inter-row spacing of 0.40 $\mathrm{m}$, with 60 plants $\mathrm{m}^{-2}$.
\end{abstract}

\section{Palavras-chave:}

Brassica napus L. espaçamento entre linhas densidade de plantas produtividade de grãos

\section{Arranjo populacional em canola definido pelos parâmetros de adaptabilidade e estabilidade}

\begin{abstract}
R E S U M O
Propôs-se, com este trabalho, identificar o arranjo de plantas que possibilite maior produtividade de grãos com adaptabilidade e estabilidade em híbridos de canola. Os experimentos foram desenvolvidos em blocos ao acaso com quatro repetições nos 12 tratamentos da combinação entre o espaçamento entre linhas $(0,20,0,40,0,60 \mathrm{~m})$ e a densidade de plantas $\left(20,40,60\right.$ e 80 plantas $\left.\mathrm{m}^{-2}\right)$. Foram cultivados os híbridos Hyola 432 - ciclo precoce e Hyola 61 - ciclo médio, em três safras agrícolas (2008, 2009 e 2010). Foi avaliada a produtividade de grãos pelos parâmetros de adaptabilidade e estabilidade pelo modelo de Wricke e de Eberhart e Russell. O arranjo de plantas para a obtenção de maior produtividade de grãos depende do genótipo cultivado. A produtividade de grãos para o Hyola 432 foi maior nos arranjos de plantas de $0,20 \mathrm{~m}$ x 60 e 0,40 m x 60 plantas $\mathrm{m}^{-2}$ e para o Hyola 61 no arranjo de $0,20 \mathrm{~m} \mathrm{x} 60$ plantas $\mathrm{m}^{-2}$, nos três anos de avaliação. No espaçamento entre linhas de $0,40 \mathrm{~m}$ e densidade de 40 e 60 plantas $\mathrm{m}^{-2}$ o Hyola 432 evidencia alta produtividade, adaptabilidade a ambientes amplos e estabilidade. No Hyola 61 a alta produtividade com adaptabilidade geral foi obtida no espaçamento entre linhas de $0,40 \mathrm{~m}$ com 60 plantas $\mathrm{m}^{-2}$.
\end{abstract}




\section{INTRODUCTION}

The state of Rio Grande do Sul has the highest production of rapeseed in Brazil, with mean of 39.5 thousand tons and yield of $1,320 \mathrm{~kg} \mathrm{ha}^{-1}$ (CONAB, 2013). Rapeseed yield has great variations along the cultivation years. These variations can occur due to the differences in meteorological conditions from year to year (Dalmago et al., 2009), losses through natural threshing, due to uneven maturation of siliques (Silva et al., 2011) and management practices, such as sowing spacing and density (Shahin \& Valiollah, 2009).

Rapeseed management practices were reported by Tomm (2007), who indicates orchards with 40 plants $\mathrm{m}^{-2}$, uniformly distributed, with the lowest spacing available in the sowing machine; however, this author also highlights successful results with spacings of up to $45 \mathrm{~cm}$ between rows. In this context, Chavarria et al. (2011) point out that the efforts in research and development are incipient for rapeseed, and there is a lack of technical-scientific information on crop management, such as adequate inter-row spacing and sowing density.

Rapeseed is a grain-producing species with phenotypical plasticity, which determines plant morphological adjustment to different conditions of space and light, thus showing compensating mechanisms among the different plant components, which alter the relationships of source and sink (Jullien et al., 2011). Therefore, an adequate plant arrangement can contribute to higher uniformity of silique maturation, as well as to the increase in grain yield (Bandeira et al., 2013). Shahin \& Valiollah (2009) point out that rapeseed yield is more stable when plants are uniformly distributed. Therefore, indicating a plant arrangement that allows high grain yield and silique maturation uniformity is of great importance for the consolidation of the crop in Brazil.

The use of biometric models that allow estimating the stability of grain yield represents valuable information for the recommendation of cultivars and/or adjustment of the best crop management (Silva \& Duarte, 2006). Among these models, adaptability and stability models, through the quantification of their parameters, aim to define the response of genotypes to specific environmental conditions (Benin et al., 2005). There are different models for the determination of these parameters. The method of Eberhart \& Russell (1966) is based on simple linear regression of the genotype as a function of environmental indices. The linear regression coefficient $\left(\beta_{1 \mathrm{i}}\right)$ is a measurement of the adaptability and the standard deviations $\left(\sigma_{\mathrm{di}}^{2}\right)$ are a measurement of the stability. The ideal genotype is that with regression coefficient equal to one and with the lowest regression deviation possible (Cruz \& Carneiro, 2003). The model of Wricke (1965) employs the methodology called ecovalence, which decomposes the sum of the squares of the interaction into parts attributed to each genotype and considers as the most stable the one with the lowest estimate of ecovalence $\left(\omega_{\mathrm{i}}\right)$ (Cruz \& Carneiro, 2003). The models of Wricke (1965) and Eberhart \& Russell (1966) have been used in various studies with grain-producing species, such as in Silva \& Duarte (2006) with soybean, Cargnelutti Filho et al. (2007) with corn and Pereira et al. (2009), with bean.

Rapeseed performance is directly associated with management practices and the meteorological conditions during its cycle, notably air temperature and rainfall (Dalmago et al., 2009). The need for the generation of scientific information in order to improve the state of the art regarding the management practices for the success of this crop must be highlighted.

This study aimed to identify the arrangement of plants that allows higher grain yield with adaptability and stability in rapeseed hybrids.

\section{Material ANd Methods}

The studies were carried out in the agricultural years of 2008, 2009 and 2010, at the Regional Institute of Rural Development (IRDeR), linked to the Department of Agrarian Studies of the Regional University of Northwestern Rio Grande do Sul (UNIJUÍ), in Augusto Pestana-RS, Brazil (28 26’306" $\mathrm{S}$; 54 $00^{\circ}$ '58” W; $298 \mathrm{~m}$ ). The soil in the experimental area is classified as typical distroferric Red Latosol (Santos et al., 2006). The climate in the region is Cfa (subtropical), according to Köppen's classification.

The experiments were set in a randomized block design, with four replicates. The treatments of plant arrangements considered three inter-row spacings $(0.20,0.40$ and $0.60 \mathrm{~m})$ and four plant densities $\left(20,40,60\right.$ and 80 plants $\left.\mathrm{m}^{-2}\right)$ in the following combinations: $0.20 \times 20,0.20 \times 40,0.20 \times 60,0.20 \times$ $80,0.40 \times 20,0.40 \times 40,0.40 \times 60,0.40 \times 80,0.60 \times 20,0.60 \times 40$, $0.60 \times 60$ and $0.60 \times 80$. The hybrids Hyola 432, with early cycle, and Hyola 61, with medium cycle, were used in this study. The experimental unit consisted of five 5-m-long rows, changing the dimensions of the area according to the proposed spacings.

Soil correction and crop fertilization were performed according to the soil analysis for an expected grain yield of approximately $1,500 \mathrm{~kg} \mathrm{ha}^{-1}$. Sowing was manually performed in the third week of May, in the years of 2008 and 2009, and in the last week of June, in 2010, as recommended by the agroclimatic zoning for rapeseed. An amount of seeds greater than the minimum necessary for each density was used for sowing. The final adjustment in the number of plants, in order to obtain the desired plant densities, was performed through thinning, when plants had two to three leaves. The analysed variable was grain yield $\left(\mathrm{kg} \mathrm{ha}^{-1}\right)$, which was estimated through the manual harvest of the entire plot and the drying of samples until constant weight, close to $12 \%$. Plots were harvested in late October in 2008 and 2009, and in late November in 2010.

The analysis of variance was performed to identify the interaction Cultivation Year versus Plant Arrangement in rapeseed hybrids with different maturation cycles. Then, the means were grouped through the method Scott-Knott at 0.05 probability level. The parameters adaptability and stability were estimated through the method of simple regression of Eberhart \& Russell (1966) and stability through the method of Wricke (1965). The stability model proposed by Wricke (1965) considers as stable the genotypes with low values of ecovalence $\left(\omega_{\mathrm{i}}\right)$. In the methodology proposed by Eberhart \& Russell (1966), genotypes with regression deviations $\left(\sigma_{\mathrm{di}}^{2}\right)$ equal to zero are considered as stable and those with $\sigma_{\mathrm{di}}^{2} \neq 0$ are considered as unstable. Adaptability is given by the linear regression coefficient $\left(\beta_{\mathrm{i}}\right)$, which classifies genotypes adapted to favorable 
environments $\left(\beta_{\mathrm{i}}>1\right)$, genotypes adapted to unfavorable environments $\left(\beta_{i}<1\right)$ and those with wide adaptation $\left(\beta_{i}=1\right)$ (Cruz \& Carneiro, 2003). The analysis were performed using the computational program GENES (Cruz, 2006).

\section{Results AND Discussion}

According to the analysis of variance, there were significant effects of the isolated factors (plant arrangement and cultivation year) on the grain yields of the evaluated hybrids (Table 1). In addition, the interaction between factors also caused significant effects and, thus, it needed to be detailed regarding plant arrangement by evaluation year. The mean squares for the cultivation years showed greater effects of this factor as compared to plant arrangement, regardless of the tested hybrid. Such condition evidences more pronounced effects of cultivation year compared with plant arrangement, indicating that the meteorological conditions of a certain year were more decisive for the alterations in grain yield. Furthermore, the mean square for the hybrid Hyola 432 was higher than that for Hyola 61, which raises the hypothesis of higher instability of this hybrid regarding the expression of grain yield.

Rapeseed grain yield is a result of the interaction between genetic potential, management techniques, such as nitrogen fertilization (Kaefer et al., 2014), and meteorological conditions occurring during the crop cycle, associated with air temperature (Dalmago et al., 2009). Marjanović-Jeromela et al. (2011) attributed yield variations in winter rapeseed along the cultivation years to the irregular availability of rainfall during the crop cycle, especially in the grain filling stage. In addition, Bandeira et al. (2013) pointed out that an inadequate plant arrangement in this species also tends to promote variations in grain yield, especially because it is a species with indeterminate growth habit (Koenig et al., 2011).

For Hyola 432, the highest grain yields in 2008 were obtained with the arrangements of $0.20 \times 60$ and $0.40 \times 60$ (Table 2); in 2009, the highest yield occurred for the condition of $0.20 \times 60$ and, in 2010, the best response was observed in the arrangement of $0.40 \times 60$, similar to the year of 2008 . The inter-row spacings of 0.20 and $0.40 \mathrm{~m}$ were the most adequate conditions for this hybrid, compared with Hyola 61, provided that a plant density of 60 plants $\mathrm{m}^{-2}$ is maintained (Table 2).

According to the overall mean, the hybrid Hyola 432 showed superiority of grain yield (S) in the inter-row spacings

Table 1. Summary of the analysis of variance for grain yield as a function of plant arrangement in different cultivation years for two rapeseed hybrids

\begin{tabular}{|c|c|c|c|}
\hline \multirow[t]{2}{*}{ Variation source } & \multirow[t]{2}{*}{ DF } & \multicolumn{2}{|c|}{$\begin{array}{c}\text { Mean square } \\
\text { Grain yield }\left(\mathrm{kg} \mathrm{ha}^{-1}\right)\end{array}$} \\
\hline & & Hyola 432 & Hyola 61 \\
\hline Block & 3 & 3,782 & 68 \\
\hline Plant arrangement (PA) & 11 & 403,869 * & 179,073 * \\
\hline Cultivation years (CY) & 2 & $3,867,841$ * & 849,428 * \\
\hline$P A \times C Y$ & 22 & 69,256 * & 105,760 * \\
\hline Error & 105 & 5,408 & 5,562 \\
\hline Total & 143 & - & - \\
\hline Overall mean & & 983 & 876 \\
\hline CV (\%) & - & 7 & 8 \\
\hline
\end{tabular}

*Significant at 0.05 probability level by $F$ test; DF - Degrees of freedom
Table 2. Mean grain yield as a function of plant arrangements in the cultivation years of two rapeseed hybrids

\begin{tabular}{|c|c|c|c|c|c|}
\hline \multirow{2}{*}{$\begin{array}{l}\text { Plant arrangement } \\
\text { (plants } \mathrm{m}^{-2} \text { ) }\end{array}$} & \multicolumn{3}{|c|}{ Years/Grain yield } & \multirow{2}{*}{$\begin{array}{l}\text { Overall } \\
\text { Mean }\end{array}$} & \\
\hline & 2008 & 2009 & 2010 & & \\
\hline \multicolumn{6}{|c|}{ Hyola 432 (early cycle) } \\
\hline $0.20 \mathrm{~m} \times 20$ & $756 \mathrm{Bc}$ & $1164 \mathrm{Ae}$ & $609 \mathrm{Cd}$ & 843 & \\
\hline $0.20 \mathrm{~m} \times 40$ & $896 \mathrm{Bb}$ & $1226 \mathrm{Ae}$ & $717 \mathrm{Cc}$ & 946 & \\
\hline $0.20 \mathrm{~m} \times 60$ & $1143 \mathrm{Ba}$ & $1918 \mathrm{Aa}$ & $877 \mathrm{Cb}$ & 1313 & S \\
\hline $0.20 \mathrm{~m} \times 80$ & $973 \mathrm{Bb}$ & $1516 \mathrm{AC}$ & $890 \mathrm{Bb}$ & 1126 & \\
\hline $0.40 \mathrm{~m} \times 20$ & $925 \mathrm{Bb}$ & $1199 \mathrm{Ae}$ & $716 \mathrm{Cc}$ & 947 & \\
\hline $0.40 \mathrm{~m} \times 40$ & $953 \mathrm{Bb}$ & $1361 \mathrm{Ad}$ & $890 \mathrm{Bb}$ & 1068 & \\
\hline $0.40 \mathrm{~m} \times 60$ & $1129 \mathrm{Ba}$ & $1713 \mathrm{Ab}$ & $1022 \mathrm{Ca}$ & 1288 & S \\
\hline $0.40 \mathrm{~m} \times 80$ & $902 \mathrm{Bb}$ & $1312 \mathrm{Ad}$ & 753 Cc & 989 & \\
\hline $0.60 \mathrm{~m} \times 20$ & $747 \mathrm{Bc}$ & $1021 \mathrm{Af}$ & $433 \mathrm{Ce}$ & 733 & I \\
\hline $0.60 \mathrm{~m} \times 40$ & $918 \mathrm{Ab}$ & $975 \mathrm{Ag}$ & $661 \mathrm{Bc}$ & 851 & \\
\hline $0.60 \mathrm{~m} \times 60$ & $985 \mathrm{Ab}$ & $1084 \mathrm{Af}$ & $575 \mathrm{Bd}$ & 881 & \\
\hline $0.60 \mathrm{~m} \times 80$ & $990 \mathrm{Ab}$ & $934 \mathrm{Ag}$ & $520 \mathrm{Bd}$ & 815 & \\
\hline Mean & $943 \mathrm{~B}$ & $1285 \mathrm{~A}$ & $722 \mathrm{C}$ & & \\
\hline \multicolumn{6}{|c|}{ Hyola 61(medium cycle) } \\
\hline $0.20 \mathrm{~m} \times 20$ & $624 \mathrm{Cc}$ & $966 \mathrm{Ac}$ & $791 \mathrm{Be}$ & 793 & \\
\hline $0.20 \mathrm{~m} \times 20$ & $585 \mathrm{Cc}$ & $1381 \mathrm{Aa}$ & $1007 \mathrm{Bc}$ & 991 & \\
\hline $0.20 \mathrm{~m} \times 40$ & $769 \mathrm{Cb}$ & $1238 \mathrm{Ab}$ & $1103 \mathrm{Bb}$ & 1037 & S \\
\hline $0.20 \mathrm{~m} \times 60$ & $663 \mathrm{Bb}$ & $1039 \mathrm{Ac}$ & $1111 \mathrm{Ab}$ & 937 & \\
\hline $0.20 \mathrm{~m} \times 80$ & $586 \mathrm{Cc}$ & $962 \mathrm{Ac}$ & $733 \mathrm{Be}$ & 760 & \\
\hline $0.40 \mathrm{~m} \times 20$ & $1000 \mathrm{Aa}$ & $1020 \mathrm{Ac}$ & $965 \mathrm{Ac}$ & 995 & \\
\hline $0.40 \mathrm{~m} \times 40$ & $907 \mathrm{Ba}$ & $881 \mathrm{Bd}$ & $1191 \mathrm{Aa}$ & 993 & \\
\hline $0.40 \mathrm{~m} \times 60$ & $713 \mathrm{Bb}$ & $781 \mathrm{Be}$ & $1268 \mathrm{Aa}$ & 921 & \\
\hline $0.40 \mathrm{~m} \times 80$ & $677 \mathrm{Ab}$ & $692 \mathrm{Ae}$ & $553 \mathrm{Bf}$ & 641 & I \\
\hline $0.60 \mathrm{~m} \times 20$ & $731 \mathrm{Bb}$ & $981 \mathrm{Ac}$ & $815 \mathrm{Be}$ & 842 & \\
\hline $0.60 \mathrm{~m} \times 40$ & $745 \mathrm{Bb}$ & $886 \mathrm{Ad}$ & $913 \mathrm{Ad}$ & 848 & \\
\hline $0.60 \mathrm{~m} \times 60$ & $676 \mathrm{Bb}$ & $716 \mathrm{Be}$ & $882 \mathrm{Ad}$ & 758 & \\
\hline Mean & $723 \mathrm{~B}$ & $962 \mathrm{~A}$ & $944 \mathrm{~A}$ & & \\
\hline
\end{tabular}

Means followed by the same lowercase letters in the column and uppercase letters in the row do not differ at 0.05 probability level, according to the model of Scott-Knott; S - Superior to the mean +1 standard deviation; and I - Inferior to the mean +1 standard deviation

of 0.20 and $0.40 \mathrm{~m}$ associated with the density of 60 plants $\mathrm{m}^{-2}$ (Table 2). The inter-row spacing of $0.20 \mathrm{~m}$ with density of 40 plants $\mathrm{m}^{-2}$ also promoted the highest grain yield for Hyola 61 . However, in the inter-row spacing of $0.40 \mathrm{~m}$, although Hyola 432 was not superior to Hyola 61, the obtained means were close to those of the arrangement with the highest yield at densities of 20 and 40 plants $\mathrm{m}^{-2}$.

Rapeseed grain yield, besides showing differences regarding the cultivation years and plant arrangement, evidenced different responses for the tested hybrids. Bandeira et al. (2013) observed higher grain yield in spacing of $17 \mathrm{~cm}$ with population density of 45 plants $\mathrm{m}^{-2}$ using the hybrid Hyola 61. On the other hand, Jacob Júnior el al. (2012) observed higher grain yield using a density of 250 thousand plants per hectare for the hybrid Toccata. Due to rapeseed phenotypical plasticity, a factor related to the growth/flowering habit, the great alterations in its morphology stand out (Sultan, 2003).

In the comparison between cultivation years for the hybrid Hyola 432, the year of 2009 was favorable to the expression of the highest grain yield, followed by 2010 and 2008, respectively, which were different (Table 2). On the other hand, Hyola 61 showed similar grain yield response in the cultivation years of 2009 and 2010, with the lowest grain yield in 2008. These results tend to characterize the hybrid Hyola 432 as the one with the highest instability for grain production, compared with Hyola 61. Studies on genetic and environmental effects show that $73 \%$ of the variation in grain yield in winter rapeseed 
is explained by the environment, $8 \%$ by difference between genotypes and $19 \%$ by the interaction genotype $\mathrm{x}$ environment (Marjanović-Jeromela et al., 2011).

Therefore, the determination of environments that are favorable and stable for rapeseed grain yield becomes relevant.
The observed results, caused by the effects of cultivation years, can also be confirmed by the analysis of the meteorological conditions during the crop cycle (Figure 1). In the year of 2009, rapeseed plants showed the highest grain yield, possibly due to the highest rainfall observed along crop cycle $(1124 \mathrm{~mm})$,
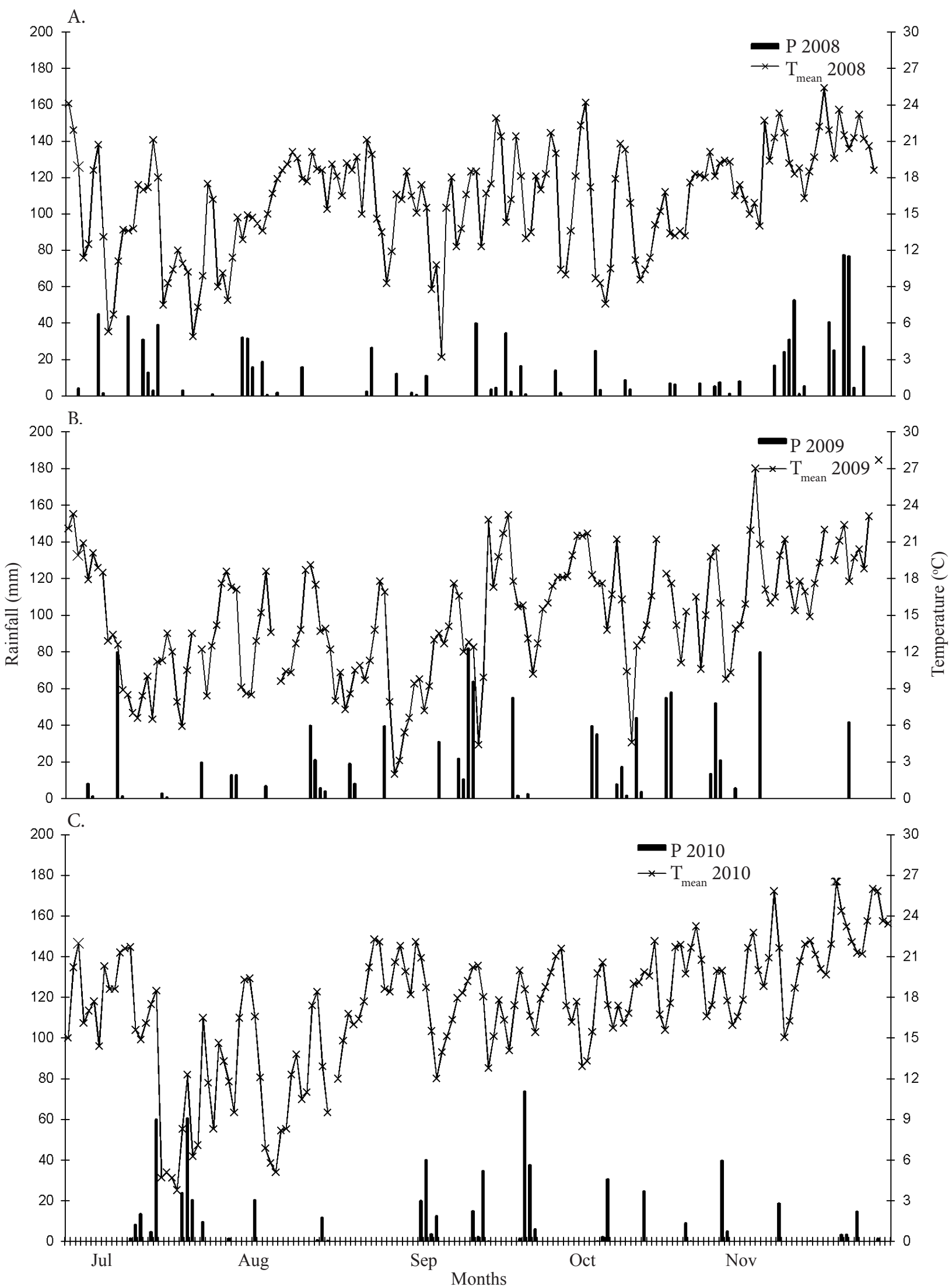

Figure 1. Meteorological data of air temperature $\left(\mathrm{T}_{\text {mean }}\right)$ and rainfall $(\mathrm{P})$ during the development of rapeseed in 2008 (A), 2009 (B) and $2010(\mathrm{C})$ 
compared with the climatological normal (1047 mm), different from that in 2008, when rainfall was lower, especially in September and, in 2010, in November, when the crop was in the stage of flowering and grain filling.

The analysis of adaptability and stability of rapeseed in different plant arrangements showed that, despite having the highest grain yield means in the arrangements of $0.20 \times 60$ and $0.40 \times 60$, the hybrid Hyola 432 showed adaptability for both favorable and unfavorable cultivation environments only in the arrangement of $0.40 \times 60$ (Table 3 ). On the other hand, there was no stability in the arrangement of $0.40 \times 60$, since $\sigma_{\mathrm{di}}^{2}$ was significant, indicating that the mean value of grain yield, although high, did not point to stability of expression in this condition.

The plant arrangements of $0.20 \times 80$ and $0.40 \times 40$ also promoted yields above $1000 \mathrm{~kg} \mathrm{ha}^{-1}$ and, despite showing wide adaptability, were not stable according to the model of Eberhart \& Russell (1966). Nevertheless, Hyola 432 in the plant arrangement of $0.40 \times 60$ was the most stable condition, according to the model of Wricke (1965), with a lower ecovalence value compared with the arrangement of $0.20 \mathrm{x}$ 60 (Table 3).

In the hybrid Hyola 61, the arrangements of $0.40 \times 60$ and $0.40 \times 80$ simultaneously promoted high grain yield and adaptability to favorable and unfavorable environments (Table 3). The plant arrangements of $0.20 \times 40,0.20 \times 60$ and $0.20 \times 80 \mathrm{~m}$ showed specific adaptability to favorable environments $\left(\beta_{1}>\right.$

Table 3. Mean grain yield and parameters of adaptability and stability in rapeseed according to Eberhart \& Russell (1966) and Wricke (1965), as a function of plant arrangement

\begin{tabular}{|c|c|c|c|c|c|c|c|}
\hline \multirow{3}{*}{$\begin{array}{c}\text { PA } \\
\text { (plants } \mathrm{m}^{-2} \text { ) }\end{array}$} & \multirow{3}{*}{$\begin{array}{c}\text { MY } \\
\left(\mathrm{kg} \mathrm{ha}^{-1}\right)\end{array}$} & & \multicolumn{5}{|c|}{ Parameters } \\
\hline & & & \multicolumn{3}{|c|}{$\begin{array}{c}\text { Eberhart \& Russell } \\
(1966)\end{array}$} & \multicolumn{2}{|c|}{$\begin{array}{l}\text { Wricke } \\
\text { (1965) }\end{array}$} \\
\hline & & & $\boldsymbol{\beta}_{1}$ & $\sigma_{\mathrm{di}}^{2}$ & $\mathrm{R}^{2}$ & $\omega_{i}$ & $\omega_{i}(\%)$ \\
\hline & \multicolumn{7}{|c|}{ Hyola 432 (early cycle) } \\
\hline $0.20 \mathrm{~m} \times 20$ & 843 & $d$ & $1.00^{\text {ns }}$ & $1.973^{\text {ns }}$ & 97.9 & 13,304 & 0.8 \\
\hline $0.20 \mathrm{~m} \times 40$ & 946 & c & $0.90^{\text {ns }}$ & $1049^{\text {ns }}$ & 99.7 & 6,551 & 0.4 \\
\hline $0.20 \mathrm{~m} \times 60$ & 1313 & $\mathrm{a}$ & $1.88^{\star}$ & $12095^{\star}$ & 97.7 & 557,843 & 36.6 \\
\hline $0.20 \mathrm{~m} \times 80$ & 1126 & b & $1.15^{\text {ns }}$ & $15997^{\star}$ & 92.4 & 84,046 & 5.5 \\
\hline $0.40 \mathrm{~m} \times 20$ & 947 & C & $0.85^{\text {ns }}$ & $1118^{\text {ns }}$ & 99.8 & 14,720 & 1.0 \\
\hline $0.40 \mathrm{~m} \times 40$ & 1068 & b & $0.86^{\text {ns }}$ & $8376^{*}$ & 92.5 & 50,139 & 3.3 \\
\hline $0.40 \mathrm{~m} \times 60$ & 1288 & $\mathrm{a}$ & $1.26^{\text {ns }}$ & $16364^{*}$ & 93.5 & 116,631 & 7.7 \\
\hline $0.40 \mathrm{~m} \times 80$ & 989 & c & $1.00^{\text {ns }}$ & $1932^{\text {ns }}$ & 98.0 & 13,198 & 0.9 \\
\hline $0.60 \mathrm{~m} \times 20$ & 733 & d & $1.02^{\text {ns }}$ & $3189^{\text {ns }}$ & 97.3 & 18,508 & 1.2 \\
\hline $0.60 \mathrm{~m} \times 40$ & 851 & d & $0.52^{*}$ & $10518^{*}$ & 78.8 & 193,561 & 12.7 \\
\hline $0.60 \mathrm{~m} \times 60$ & 881 & d & $0.85^{\text {ns }}$ & $27738^{*}$ & 80.0 & 130,860 & 8.6 \\
\hline $0.60 \mathrm{~m} \times 80$ & 815 & d & $0.65^{*}$ & $60947^{*}$ & 52.8 & 324,273 & 21.3 \\
\hline & \multicolumn{7}{|c|}{ Hyola 61 (medium cycle) } \\
\hline $0.20 \mathrm{~m} \times 20$ & 793 & b & $1.14^{\text {ns }}$ & $10656^{*}$ & 79.4 & 51,192 & 2.2 \\
\hline $0.20 \mathrm{~m} \times 40$ & 991 & a & $2.72^{*}$ & $51937^{*}$ & 83. & 635,990 & 27.3 \\
\hline $0.20 \mathrm{~m} \times 60$ & 1037 & $\mathrm{a}$ & $1.77^{*}$ & $3973^{\text {ns }}$ & 95. & 106,179 & 4.6 \\
\hline $0.20 \mathrm{~m} \times 80$ & 937 & $\mathrm{a}$ & $1.76^{*}$ & $3954^{\text {ns }}$ & 95. & 103,720 & 4.5 \\
\hline $0.40 \mathrm{~m} \times 20$ & 760 & b & $1.18^{\text {ns }}$ & $20350^{\star}$ & 69.7 & 92,018 & 4.0 \\
\hline $0.40 \mathrm{~m} \times 40$ & 995 & a & $-0.02^{\star}$ & $150 \mathrm{~ns}$ & 1. & 154,089 & 6.6 \\
\hline $0.40 \mathrm{~m} \times 60$ & 993 & a & $0.48^{\text {ns }}$ & $49364^{*}$ & 14.0 & 240,823 & 10.4 \\
\hline $0.40 \mathrm{~m} \times 80$ & 921 & a & $1.22^{\text {ns }}$ & $128308^{*}$ & 29.0 & 525,909 & 22.6 \\
\hline $0.60 \mathrm{~m} \times 20$ & 641 & C & $0.20^{\text {ns }}$ & $8854^{*}$ & 12.3 & 245,545 & 10.6 \\
\hline $0.60 \mathrm{~m} \times 40$ & 842 & b & $0.76^{\text {ns }}$ & $10227^{\star}$ & 69.1 & 54,224 & 2.3 \\
\hline $0.60 \mathrm{~m} \times 60$ & 848 & b & $0.66^{\text {ns }}$ & $624^{\mathrm{ns}}$ & 95.3 & 19,088 & 0.8 \\
\hline $0.60 \mathrm{~m} \times 80$ & 758 & b & $0.48^{\text {ns }}$ & $13829 *$ & 35.6 & 97,951 & 4.2 \\
\hline
\end{tabular}

$\beta_{1}$ - Adaptability coefficient; $\sigma^{2}{ }_{d}-$ Regression deviations; $R^{2}-$ Coefficient of determination, obtained by the method of Eberhart \& Russell (1966); $\omega_{i}$ - Stability coefficient obtained by the method of Wricke (1965); *Significant; nsNot significant by F test and t-test
1). Rapeseed plants in the inter-row spacing of $0.20 \mathrm{~m}$ and at densities of 60 and 80 plants $\mathrm{m}^{-2}$ showed stability according to the model of Eberhart \& Russell (1966). The arrangement of $0.40 \times 40$, besides promoting high grain yield mean, showed an interesting peculiarity; although it showed stability, it indicated specific adaptability to unfavorable environments. This condition could be more appropriate for the recommendation to farmers with lower technological support or from areas with higher agro-ecological variations. In general, the inter-row spacing of $0.40 \mathrm{~m}$ with density of 60 plants $\mathrm{m}^{-2}$ is the most adequate condition, because it shows high grain yield mean with general adaptability (Table 3 ).

The analysis of adaptability and stability have been increasingly used in the identification of cultivars with more stable and predictable behavior regarding the environmental variations (Silva \& Duarte, 2006), as well as in the definition of more adequate cultivation techniques (Krüger et al., 2011). It should be pointed out that there could be different responses between the methods of estimation of adaptability and stability (Cargnelutti Filho et al., 2007) as observed in the present study. This is somehow expected, since the method of Wricke (1965) indicates that the stability does not depend on mean yield and adaptability to general environments, favorable and unfavorable, contrary to the model of Eberhart \& Russell (1966).

In the present study, it was possible to indicate, using stability and adaptability models, a more adequate plant arrangement for two rapeseed hybrids, considering the meteorological conditions of different seasons. This information is of great importance because these are species with indeterminate growth habit, responsive to alterations in plant arrangement and with lack of more specific recommendations for the cultivation regions. The parameters of adaptability and stability contribute to management adjustments and better recommendation of cultivars. This is observed in species of agricultural interest, such as corn for grain production (Cargnelutti Filho et al., 2007), oat for the content of betaglucan (Crestani et al., 2010) and soybean for oil and protein contents in the seeds (Rodrigues et al., 2014).

\section{Conclusions}

1. The arrangement of plants for obtaining the highest grain yield depends on the cultivated genotype.

2. Grain yield was higher in the arrangements of $0.20 \mathrm{~m} \mathrm{x}$ 60 plants $\mathrm{m}^{-2}$ and $0.40 \mathrm{~m} \mathrm{x} 60$ plants $\mathrm{m}^{-2}$ for Hyola 432 and in the arrangement of $0.20 \mathrm{~m} \mathrm{x} 60$ plants $\mathrm{m}^{-2}$ for Hyola 61, in the three evaluation years.

3. In the inter-row spacing of $0.40 \mathrm{~m}$ and densities of 40 and 60 plants $\mathrm{m}^{-2}$, Hyola 432 shows high yield, adaptability to wide environments and stability. For Hyola 61, high yield with general adaptability was obtained in the inter-row spacing of $0.40 \mathrm{~m}$ with 60 plants $\mathrm{m}^{-2}$.

\section{Literature Cited}

Bandeira, T. P.; Chavarria, G.; Tomm, G. O. Desempenho agronômico de canola em diferentes espaçamentos entre linhas e densidades de plantas. Pesquisa Agropecuária Brasileira, v.48, p.1332-1341, 2013. http://dx.doi.org/10.1590/S0100-204X2013001000004 
Benin, G. ; Carvalho, F. I. F. de; Oliveira, A. C.; Lorencetti, C.; Vieira, E. A.; Coimbra, J. L. M.; Valério, I. P.; Floss, E. L.; Bertan, I.; Silva, G. A. G. Adaptabilidade e estabilidade em aveia em ambientes estratificados. Ciência Rural, v.35, p.295-302, 2005. http://dx.doi. org/10.1590/S0103-84782005000200008

Cargnelutti Filho, A.; Perecin, D.; Malheiros, E. B.; Guadagnin, J. P. Comparação de métodos de adaptabilidade e estabilidade relacionados à produtividade de grãos de cultivares de milho. Bragantia, v.66, p.571-578, 2007. http://dx.doi.org/10.1590/S000687052007000400006

Chavarria, G.; Tomm, G. O.; Muller, A.; Mendonça, H. F.; Mello, N.; Betto, S. Índice de área foliar em canola cultivada sob variações de espaçamento e de densidade de semeadura. Ciência Rural, v.41, p.2084-2089, 2011. http://dx.doi.org/10.1590/S010384782011001200008

CONAB - Companhia Nacional de Abastecimento. Acompanhamento de safra brasileira: Grãos, décimo segundo levantamento, setembro 2013/Companhia Nacional de Abastecimento - Brasília: CONAB, 2013. 30p.

Crestani, M.; Carvalho, F. I. F. de; Oliveira, A. C. de; Silva, J. A. G. da; Gutkoski, L. C.; Sartori, J. F.; Barbieri, R. L.; Baretta, D. Conteúdo de $\beta$-glucana em cultivares de aveia branca cultivadas em diferentes ambientes. Pesquisa Agropecuária Brasileira, v.45, p.261-268, 2010.

Cruz, C. D. Programa Genes: Biometria. Viçosa: UFV, 2006. 382p.

Cruz, C. D.; Carneiro, P. C. S. Modelos biométricos aplicados ao melhoramento genéticos. Viçosa: UFV, 2003. 585p.

Dalmago, G. A.; Cunha, G. R. da; Tomm, G. O.; Santi, A.; Pires, J. L. F. Canola, In: Monteiro, J. E. B. A. (org.). Agrometeorologia dos cultivos. 1.ed. Brasília: INMET, 2009. v.1, p.131-149.

Eberhart, S. A.; Russell, W. A. Stability parameters for comparing varieties. Crop Science, v.6, p.6-40, 1966. http://dx.doi. org/10.2135/cropsci1966.0011183X000600010011x

Jacob Júnior, E. A.; Mertz, L. M.; Henning, F. A.; Quílon, I. R.; Maia, M. de S.; Altisent, J. M. D. Changes in canola plant architecture and seed physiological quality in response to different sowing densities. Revista Brasileira de Sementes. v.34, p.14-20, 2012. http://dx.doi.org/10.1590/S0101-31222012000100002

Jullien, A.; Mathieu, A.; Allirand, J. M.; Pinet, A.; Reffye, P de; Courne, P-H; Ney, B. Characterization of the interactions between architecture and source-sink relationships in winter oilseed rape (Brassica napus) using the GreenLab model. Annals of Botany, v.107, p.765-779, 2011. http://dx.doi.org/10.1093/aob/mcq205

Kaefer, J. E.; Guimarães, V. F.; Richart, A.; Tomm; G. O.; Müller, A. L. Produtividade de grãos e componentes de produção da canola de acordo com fontes e doses de nitrogênio. Pesquisa Agropecuária Brasileira, v.49, p.273-280, 2014. http://dx.doi.org/10.1590/S0100204X2014000400005
Koenig, R. T.; Hammac, W. A.; Pan, W. L. Canola growth, development, and fertility. Washington: Washington State University, 2011. 6p.

Krüger, C. A. M. B.; Medeiros, S. L. P.; Silva, J. A. G. da.; Gaviraghi, J. Herdabilidade e correlação fenotípica de caracteres relacionados à produtividade de grãos e à morfologia da canola. Pesquisa Agropecuária Brasileira, v.46, p.1625-1632, 2011.

Marjanović-Jeromela, A.; Nagal, N.; Gvozdanović-Varga, J.; Hristov, N.; Kondić-Špika, A.; Vasić, M.; Marinković, R. Genotype by environment interaction for seed yield per plant in rapeseed using AMMI model. Pesquisa Agropecuária Brasileira, v.46, p.174-181, 2011.

Pereira, H. S.; Melo, L. C.; Peloso, M. J. D.; Faria, L. C. de; Costa, J. G. C. da; Díaz, J. L. C.; Rava, C. A.; Wendland, A. Comparação de métodos de análise de adaptabilidade e estabilidade fenotípica em feijoeiro-comum. Pesquisa Agropecuária Brasileira, v.44, p.374383, 2009. http://dx.doi.org/10.1590/S0100-204X2009000400007

Rodrigues, J. I. da S.; Cruz, C. D.; Piovesan, N. D.; de Barros, E. G.; Moreira, M. A. Biometric analysis of protein and oil contents of soybean genotypes in different environments. Pesquisa Agropecuária Brasileira, v.49, p.475-482, 2014. http://dx.doi. org/10.1590/S0100-204X2014000600009

Santos, H. G. dos; Jacomine, P. K. T.; Anjos, L. H. C. dos; Oliveira, V. A. de; Oliveira, J. B. de; Coelho, M. R.; Lumbreras, J. F.; Cunha, T. J. F. (ed.). Sistema brasileiro de classificação de solos. Rio de Janeiro: Embrapa Solos, 2006. 306p.

Shahin, Y.; Valiollah, R. Effects of row spacing and seeding rates on some agronomical traits of spring canola (Brassica napus $\mathrm{L}$,) cultivars. Journal of Central European Agriculture, v.10, p.115122, 2009.

Silva, J. A. G. da; Motta, M. B. da; Wunsch, J. A.; Crestani, M.; Fernandes, S.B.V.; Berto, J. L.; Gaviraghi, F.; Martins, J. A. K.; Wagner, J. F.; Valentini, A. P. F.; Zambonato, F. Dessecação em pré-colheita como estratégia de manejo na redução de perdas por fatores de ambiente em canola. Revista Brasileira de Agrociência, v.16, p.151-158, 2011.

Silva, W. C. J.; Duarte, J. B. Métodos estatísticos para estudo de adaptabilidade e estabilidade fenotípica em soja. Pesquisa Agropecuária Brasileira, v.41, p.23-30, 2006. http://dx.doi. org/10.1590/S0100-204X2006000100004

Sultan, S. E. Phenotypic plasticity in plants: A case study in ecological development. Evolution \& Development, v.5, p.25-33, 2003. http:// dx.doi.org/10.1046/j.1525-142X.2003.03005.x

Tomm, G. O. Indicativos tecnológicos para produção de canola no Rio Grande do Sul. Passo Fundo: Embrapa Trigo, 2007. 32p. <http://www,cnpt,embrapa,br/culturas/canola/p_sp03_2007,pdf> 10 Mai. 2014.

Wricke, G. Zur berechning der okovalenz bei sommerweizen und hafer. Zeitschrift fur Pflanzenzuchtung, v.52, p.127-138, 1965. 